\title{
Regulatory Reconstruction of Waste Management to Achieve Efficient and Sustainable Environmental Management
}

\author{
Moh. Sidik and Edy Lisdiyono*
}

Faculty of Law, Universitas 17 Agustus 1945, Semarang, Indonesia

\begin{abstract}
One of the fundamental problems related to environmental management that continues to receive attention is waste. Likewise, waste management is still a serious problem faced by Pemalang, Central Java. This study seeks to discuss the reconstruction of waste management regulations in Pemalang Regency, Central Java, Indonesia. The results showed that the prevailing regulation is suboptimal and inefficient due to the presence of two concurrent waste management sectors, i.e., public work and environmental department. Besides, the community's low participation at the village level also hinders waste management. Therefore, waste management regulation reconstruction is necessary to address the issues of waste management in Pemalang Regency. The results of the present study highlight the legal aspects and demonstrated the reconstruction of the waste management regulation in Pemalang Regency to obtain sustainable and efficient environmental management. The result of the study showed that waste management could be optimized by focusing on one sector, i.e., the environmental department. In addition, the subdistrict or village government should be given the authority to participate in managing waste, which will create a synergy between the government and the community.
\end{abstract}

Keywords: Waste management, regulation, environmental law, local government, Indonesia.

\section{INTRODUCTION}

The waste problem, which is getting more and more complex, is a universal problem faced by each individual, society and government. Based on Article 1 of Indonesian Law No. 18 of 2008 concerning Waste Management, the definition of waste is the remains of human daily activities and/or natural processes in solid form (Meidiana \& Gamse, 2010; Zurbrügg et al., 2012). According to Basuki et al. (2020), poor waste and waste management, increased use of materials that cannot be degraded by nature affect the quality of the environment. Waste management is interesting to study because even though the legal regulations at the central level are the same, in reality, and implementation at the regional level is different.

In general, domestic waste in Indonesia consists mostly of organic or biodegradable waste (58\%), plastic $(14 \%)$, and paper ( $9 \%)$, while the rest is glass, metal, wood, and so on. Java is an island that produces a higher waste generation rate $(55.1 \%$ of the total waste generation) when compared to the combined total waste generated by residents in other islands (Trisyanti et al., 2014). This is also the case in Pemalang Regency. The Environmental Services of Pemalang Regency (2018) revealed the rate of waste generation between 2013-2018 continues to increase, in line with the increase in population. Garbage is an important environmental problem in Pemalang Regency which

*Address correspondence to this author at the Faculty of Law, Universitas 17 Agustus 1945, Semarang, Jl. Pawiyatan Luhur Bendan Dhuwur, Semarang, Central Java 50235, Indonesia; Tel: 024-8446280;

E-mail: edylisdi.untagsmg@gmail.com handling must be maximized immediately. The low level of public concern for environmental cleanliness and health also contributes to a dirty environmental condition (Tacconi et al., 2019). The existence of Pemalang regional regulations No. 13 of 2012 regarding waste management has not yet fully answered the problem of waste management in areas that are closely related to the issue of fulfilling the basic rights of the community to a sustainable environment. The increasing amount of waste generation, unsustainable regulations at the regional level, and the lack of community participation at the village level are problems that hinder waste management in Pemalang Regency. Therefore, this study focuses on environmental law, mainly related to central government regulations and the reconstruction of local government regulations in waste management as an effort to fulfill the environment in a sustainable manner in overcoming the negative impact of waste on environmental sustainability, which includes waste management in Pemalang Regency. Several works can be used as references in research. Candrakirana (2015) examined the management of household waste and the results showed the nonoptimal management with the main factors of education level, family income, hygiene behavior, and knowledge of regulations. Umar (2018) also showed the effectiveness of Ambon Regional Regulation concerning Waste Management in providing access to waste services. In this context, this study seeks to discuss the reconstruction of waste management regulations in Pemalang Regency, Central Java, Indonesia. 


\section{REGULATORY CONSTRUCTION AT THE WASTE MANAGEMENT}

The waste management regulations issued by the government-run from central to regional levels. Three laws regulate waste management regulations, namely Law No. 18 of 2008 concerning Waste Management, Law No. 23 of 2009 concerning Environmental Protection and Management, and Law No. 23 of 2014 concerning Regional Government (Muawanah et al., 2018). In detail, the Law contains the process of protecting and managing the environment from planning to law enforcement as well as the division of authority for waste management at each level of government (Ali et al., 2021). The authority for waste management is based on Law No. 23 of 2014, which explains that the authority for solid waste lies in two concurrent government affairs, namely government in the field of Public Works and Spatial Planning, and government affairs in the environmental sector. This division certainly has an impact on its implementation because it is managed by two ministries at the central level, namely the Ministry of Environment and the Ministry of Public Works and Public Housing. Meanwhile, at the regional level which implements regulations in real terms, it collides with Regional Regulations, where each region has its own regulations, adjusted to the needs of each region, both at the provincial and district/city levels (Adiansyah, 2020).

The Central Java Provincial Government has regulations related to waste management regulations which are regulated in the Regional Regulation of the Province of Central Java No. 3 of 2014 concerning Waste Management in Central Java. Meanwhile, at the lower level, waste management in Pemalang Regency is based on Pemalang Regency Regional Regulation No. 13 of 2012 concerning Waste Management. At least there is a legal level that regulates waste management regulations in the Pemalang Regency, including the Law, Regional Regulations of Central Java Province, and Regional Regulations of Pemalang Regency. In reality, regulations governing waste management, when viewed comprehensively by level, still show obstacles in their implementation. There is a misalignment of implementation at the central and regional levels which has triggered the ineffective implementation of waste management, especially at the regional level.

In addition, barriers related to these regulations include the following. First, the shift in authority for waste management, which was originally the responsibility of the public works sector, then technically waste management also becomes the responsibility of the environmental sector based on Law No. 23 of 2014. The existence of waste management authority that is imposed on two fields can cause inefficiency because it is needed deep coordination between the two fields. Second, the area of authority in the central government in the waste subsector lies in two areas of authority, namely the Spatial Planning Public Works and the Environment Sector, however, in Provinces and regencies/cities the authority for solid waste is the responsibility of the Environmental Agency so that in the regions there is a need for division of authority between Spatial Planning and the Environmental Services Agency and the environment in accordance with Law 23 of 2014 concerning Regional Government.

Third, Law No. 18 of 2008 concerning Waste Management is equipped with a supervisory article, but it is not accompanied by a supervisory official in charge of supervising waste management so that it needs to be regulated in a regional regulation concerning waste management supervisory functional officers who can use Regional Environmental Supervisory Officers. in accordance with Law No. 32 of 2009 concerning Environmental Protection and Management. Fourth, Law No. 18 of 2008 concerning Waste Management Article 12 paragraph 1 reads "Everyone in the management of household waste and household-like waste is obliged to reduce and handle waste in an environmentally sound manner". This article is not accompanied by a sanction so that it does not have the power to compel it, therefore in regional regulations, it is necessary to provide sanctions for those who do not carry out these obligations. Fifth, the government and local governments have not yet regulated budget facilitation in reducing waste through the Waste Bank. Lastly, seventh, it is necessary to identify the difficulties of the Provincial Government in organizing the Final Processing Place (FPP)/Regional Integrated Waste Management Site (IWMS)

\section{RESULTS: REGULATION OF WASTE MANAGEMENT IN PEMALANG REGENCY}

Waste generation in Pemalang Regency which continues to increase can be determined by calculating the average waste produced by each individual. The average waste generation per person in Pemalang Regency is $0.40 \mathrm{~kg} / \mathrm{day}$. The waste generation index can be used to calculate waste generation by 
Table 1: Solid Waste Management in Pemalang Regency based on Legal System Theory

\begin{tabular}{|c|c|l|}
\hline No & Sub System & \\
\hline \hline 1. & Substance & Does not regulate the existence of solid waste and the role of the Village Government \\
\hline 2. & Structure & $\begin{array}{l}\text { Environmental Service of Pemalang Regency } \\
\text { Budget support for 2018 is IDR 7,406,500,000, -, in 2019 IDR 8,142,080,000, - and in 2020 IDR 7,884,040,000. } \\
\text { There is no Regional Environmental Supervisory Officers/PPLHD } \\
\text { There is no Environmental Civil Servant Investigating Officer/PPNSLH } \\
\text { Integrated Management Unit (1 unit) } \\
\text { Garbage Bank (64 units) } \\
\text { Recycling Center (17 units) } \\
\text { Composter organizer (10 units) } \\
\text { FPP/ Final Processing Place 3R (6 units) } \\
\text { Compost House (1 unit) }\end{array}$ \\
\hline 3. & Legal Culture & $\begin{array}{l}\text { Garbage has not been separated from its source } \\
\text { There are still people who throw garbage everywhere }\end{array}$ \\
\hline
\end{tabular}

multiplying it by the No. of residents. Based on the calculation results of waste generation in 2018 amounted to 515.43 tons/ day. The number of waste production will increase along with the increasing population. In an effort to overcome the waste problem, Pemalang Regency Government-issued Pemalang Regency Regional Regulation No. 13 of 2012 concerning Waste Management, where waste management efforts are carried out with two strategies, namely "reduction" and "handling" as stipulated in Article 9 and Article 10. Waste reduction strategies include activities for limiting waste generation, reusing waste and recycling waste. The success of these three strategies is largely determined by how much support and participation of waste generators from waste sources, namely individuals, institutions and society and/or the business world in implementing the $3 R$ program. The Pemalang Regency Government in carrying out waste handling is supported by the facilities and infrastructure owned, including 50 Units of Garbage Cart, 2 units of open trucks, 26 units of Dump Trucks, 6 Units of Arm Rolls, 2 units of Excavator, 2 units of Bulldozers, 114 TPS, 7 Integrated Waste Management Site (TPST) scattered in Pemalang Regency, 64 units of Garbage Bank throughout Pemalang Regency, and 1 Final Processing Site (TPA) Controlled landfill. Budget support for waste management in 2018 was IDR $7,406,500,000$, increased in 2019 to IDR 8,142,080,000 and decreased in 2020 to IDR $7,884,040,000$. The budget decline in 2020 is due to refocusing the budget for tackling the Covid-19 pandemic. Based on the results of FGDs and observations in the field, the Environmental Agency (DLH \& DPUTR) of Pemalang Regency can only handle waste in urban areas as well as provide services in regional markets. Based on the Law System
Theory of Friedman (2013), the effectiveness and success of law enforcement depend on three elements of the legal system, namely the structure of law, the substance of the law and legal culture. Regarding waste management in the Pemalang Regency based on the theory of the legal system, there are still deficiencies in the context of the legal structure, legal substance, and legal culture, as presented in Table 1.

\section{DISCUSSION: REGULATORY RECONSTRUC- TION OF WASTE MANAGEMENT}

As far as the current implementation of waste management in Pemalang Regency, it cannot be carried out efficiently due to the finding of obstacles, especially in terms of regulations. Therefore, it is necessary to reconstruct regulations in order to achieve efficiency in waste management. Pemalang Regency Regional Regulation regarding waste management after careful examination, there are several arguments behind the reconstruction of local government regulations in waste management to achieve a sustainable living environment (Turisno \& Dewi, 2021). One of the most basic arguments is the juridical argument. The development of statutory regulations changes very rapidly in response to the development of state life, laws and regulations that were born after Law No. 18 of 2008 concerning Waste Management, among others, Law No. 32 of 2009 concerning Environmental Protection and Management, Law No. 23 of 2014 concerning Regional Government, and Law No. 6 of 2014 concerning Villages.

Based on the Appendix to Law No. 23 of 2014 concerning Regional Government regarding the 
Division of Concurrent Government Affairs between the Central and Provincial Governments and Regency/ Cities, where the Waste Sub-Department is located in 2 Government Affairs, namely in government affairs in the field of Public Works and Administration Space and government affairs in the environment sector. This has an impact on its implementation where solid waste at the central government level is handled by 2 Ministries, namely the Ministry of Environment and the Ministry of Public Works and Public Housing. However, at the Provincial Government Level, it is only handled by the Environment and Forestry Service Office, and at the Regency/City Government Level it is only handled by the Regional Apparatus Organization in charge of the Environment. So that the division of solid waste affairs that is in the two fields of government needs to be accommodated in local regulations on waste management (Subki \& Lisdiyono, 2020).

According to Rahadian (2016), sustainable development is a human effort to improve the quality of life while still trying not to go beyond the ecosystem that supports life (Vörösmarty et al., 2018; Hickel, 2020; Tomislav, 2018; Wang et al., 2017). Based on juridical arguments, it is necessary to reconstruct regulations on waste management in Pemalang Regency. In reconstructing local government regulations for waste management, it is necessary to pay attention to the following principles of sustainable development. In ensuring equality and social justice, waste management must be implemented and felt by everyone with their respective rights and responsibilities. Real waste management implementation requires solid waste management at the neighborhood, Village and Regency/City levels. Waste management also requires community selfsufficiency, including funding to support the wheels of waste management. Financial support for waste management institutions established at the neighborhood, village level in order to operationalize the Integrated Waste Management Site (TPST), which is at least in every village/sub-district. In this TPST, the waste processing process is carried out, from starting to sort organic and inorganic waste again. Furthermore, the results of sorting are reused, organic waste can be used as compost, magot feed and so on. Inorganic waste can be reused or recycled. The remaining waste that cannot be utilized is further processed at the Final Processing Site (TPA) which is managed by the regency/city government. It is hoped that the village government will be able to carry out the authority that will be given by the regency government in managing waste in its area by providing TPST facilities and infrastructure and its management personnel, of course with the support of the regency/city government.

Regarding respect for diversity, a form of respect for diversity is to respect local wisdom. Local wisdom that lives and develops in each village/sub-district is an asset that can support the success of waste management. Local wisdom can be in the form of habits of mutual cooperation, mutual help and so on as well as local wisdom in the form of community social organizations that live in the community such as youth organizations, social meetings and so on. This local wisdom can be used as a vehicle for planning, implementing and evaluating the waste management process. It also needs an integrative approach as the integration of the role of stakeholders in waste management also greatly determines the success of waste management. The integrated participation of the regional apparatus organization in charge of the work unit as a source of producing waste is also very much needed. The role of the Public Works and Spatial Planning Office carries out its duties and authorities in developing systems and developing waste management. The role of the Department of Industry and Trade oversees the market work unit, shopping areas and industrial estates, and the Transportation Service oversees the terminal work unit. The regional apparatus organization is integrated into ensuring the implementation of waste management at the TPST level in each work unit.

Moreover, it needs future-oriented waste management. Today, this orientation will guarantee the quality of the environment in the future, so that the next generation can enjoy the same or better quality of the environment than the current generation. Lastly, community participation involvement. Community participation is a very important part of waste management. In essence, waste management is the obligation of the Regional Government and all components of society, which not only concerns technical issues and management systems but also concerns the behavior of community life (Candrakirana, 2015). The need for a clean and healthy life is the driving force for the realization of community participation. Coordinated community participation in waste management is in the form of limiting waste generation, sorting, transporting and processing waste. The implementation of coordinated waste management is expected to arise from the neighborhood management and the village government. The complete reconstruction of local government 


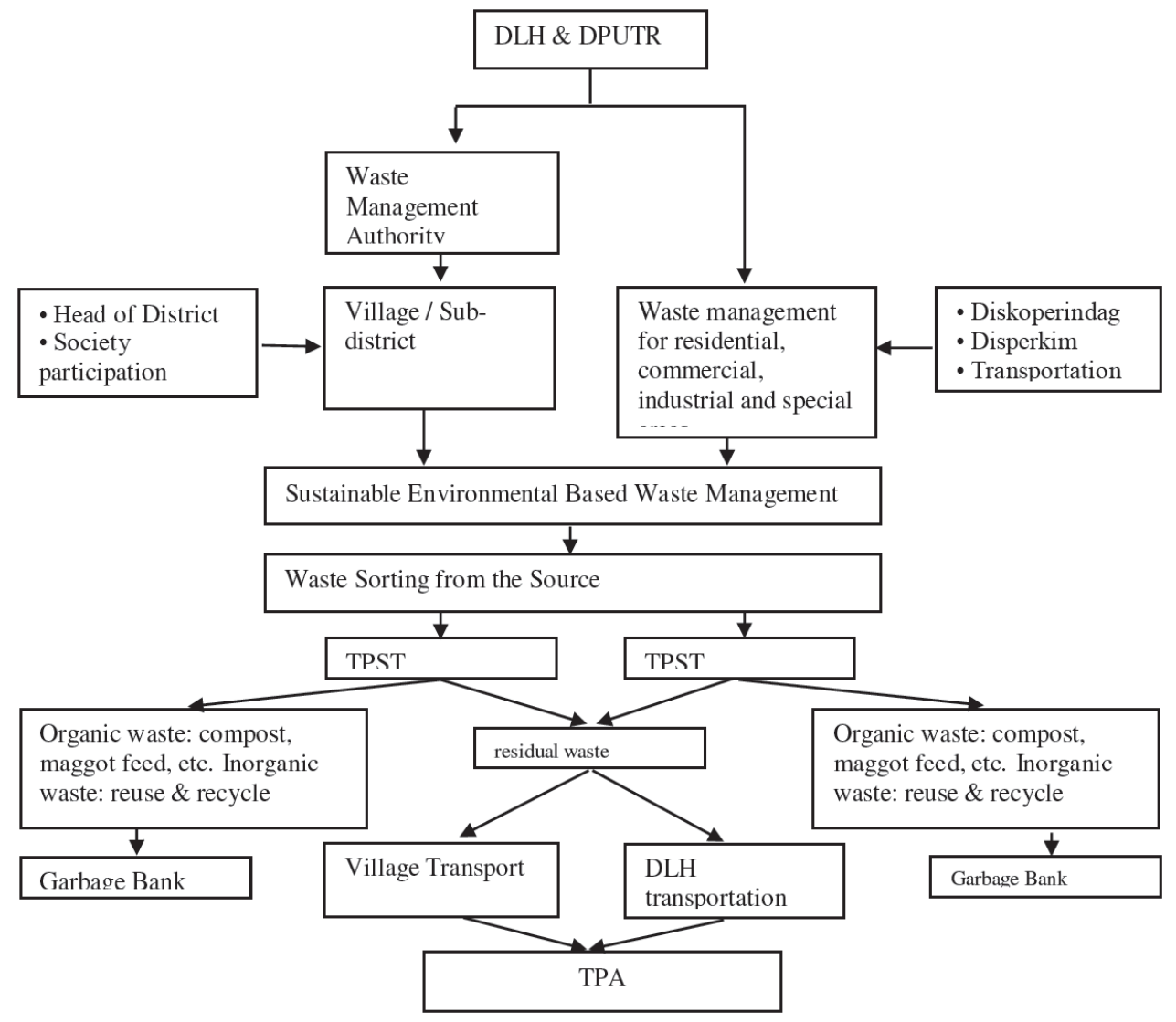

Figure 1: Reconstruction of Local Government Regulations Concerning Waste Management as Efforts to Fulfill a Sustainable Environment.

regulations on waste management is described in Figure 1.

\section{CONCLUSION}

The results showed that waste management is still a serious problem in Pemalang Regency. The implementation of waste management that is attempted still has obstacles due to inefficient regulations at the regional level, especially related to the division of waste management which is accommodated by two fields, namely handled by the Spatial Planning and the Environmental Services Agency so that the division of solid waste affairs in two areas of government is necessary accommodated in local regulations on waste management. The existing regulations have not been able to actively reach the role of the community at the village level.

This problem can be resolved by reconstructing regional waste management regulations by accommodating various laws and regulations governing waste management into regional regulations so that regional regulations are ideal to be implemented. Reconstructing regional waste management regulations by giving authority to the District and Village Governments to participate in waste management in accordance with the Minister of Home Affairs Regulation No. 44 of 2016 concerning Village Authority. Reconstructing regional waste management regulations by giving authority to Regional Environmental Supervisory Officers (PPLHD) as stipulated in Law No. 32 of 2009 concerning Environmental Protection and Management to participate in monitoring waste management

\section{REFERENCES}

Adiansyah, J. S. (2020). Correlation Analysis between River Water Quality and Community Socio-Economic Condition: Case Study of Jangkok River, Mataram City. Inkalindo Environmental Journal, 1(1), 49-61.

Ali, M., Tahir, A., Faisal, (...), Pujiyono, \& Arief, B.N. (2021) Criminological outlook of overcoming disproportionate punishment in environmental crimes. International Journal of Criminology and Sociology 10 (1), 22-32.

Basuki, K. H., Rosa, N. M., \& Alfin, E. (2020). Membangun Kesadaran Masyarakat dalam Menata Lingkungan yang Asri, Nyaman, dan Sehat. JMM (Jurnal Masyarakat Mandiri), 4(1), 1-9. https://doi.org/10.31764/jmm.v4i1.1460

Candrakirana, R. (2015). Penegakan Hukum Lingkungan dalam Bidang Pengelolaan Sampah sebagai Perwujudan Prinsip 
Good Environmental Governance di Kota Surakarta. Yustisia Jurnal Hukum, 4(3), 581-601. https://doi.org/10.20961/yustisia.v4i3.8690

Environmental Services of Pemalang Regency. (2018). Kebijakan dan Strategi Daerah (Jakstrada) Pengelolaan Sampah Rumah Tangga dan Sampah Sejenis Sampah Rumah Tangga Kabupaten Pemalang. Pemalang: Environmental Services of Pemalang Regency.

Friedman, M. L. (2013). Sistem Hukum. Bandung: Nusa Media.

Hickel, J. (2020). The sustainable development index: Measuring the ecological efficiency of human development in the anthropocene. Ecological Economics, 167, 106331. https://doi.org/10.1016/j.ecolecon.2019.05.011

Law of the Republic of Indonesia No. 23 of 2014 concerning Regional Government, 2017, reproduced by PT. Grasindo, Jakarta.

Law of the Republic of Indonesia No. 32 of 2009 concerning Environmental Protection and Management.

Law of the Republic of Indonesia No.18 of 2008 concerning Waste Management.

Meidiana, C., \& Gamse, T. (2010). Development of waste management practices in Indonesia. European journal of scientific research, 40(2), 199-210.

Muawanah, U., Yusuf, G., Adrianto, L., Kalther, J., Pomeroy, R., Abdullah, H., \& Ruchimat, T. (2018). Review of national laws and regulation in Indonesia in relation to an ecosystem approach to fisheries management. Marine Policy, 91, 150160.

https://doi.org/10.1016/j.marpol.2018.01.027

Rahadian, A.H. (2016). Strategi Pembangunan Berkelanjutan. Prosiding Seminar STIAMI, Volume III, No. 01, hIm. 46-56.

Regional Regulation of Pemalang Regency No. 13 of 2012.

Subki, T., \& Lisdiyono, E. (2020). Rights of Lawsuit for Interested Parties against Damage to Natural Resources and the Environment. Inkalindo Environmental Journal, 1(1), 67-74.
Tacconi, L., Rodrigues, R. J., \& Maryudi, A. (2019). Law enforcement and deforestation: Lessons for Indonesia from Brazil. Forest policy and economics, 108, 101943. https://doi.org/10.1016/j.forpol.2019.05.029

Tomislav, K. (2018). The concept of sustainable development: From its beginning to the contemporary issues. Zagreb International Review of Economics \& Business, 21(1), 67-94. https://doi.org/10.2478/zireb-2018-0005

Trisyanti, D., Dewi, O.C., Vidyaningrum, W., \& Wulansary. (2014). Jalan Terjal Bersihkan Negeri Fakta Sampah dan 12 Kisah Terbaik Pengelolaannya di Indonesia. Sendang Bumi Wastama.

Turisno, B.E., \& Dewi, I.G.A.G.S. (2021). Impact of coastal reclamation on environmental sustainability and tourismbased economy on the north coast of java. International Journal of Criminology and Sociology 10 (1), 695-702.

Umar, N. (2018). Efektifitas Pelaksanaan Peraturan Daerah Kota Ambon Nomor 11 Tahun 2015 tentang Pengelolaan Sampah dalam Memberikan Akses Pelayanan Sampah di Batumera Atas. Jurnal Fikratuna, Vol. 9 No. 1, pp. 54-71.

Vörösmarty, C. J., Osuna, V. R., Cak, A. D., Bhaduri, A., Bunn, S. E., Corsi, F., ... \& Uhlenbrook, S. (2018). Ecosystem-based water security and the Sustainable Development Goals (SDGs). Ecohydrology \& Hydrobiology, 18(4), 317-333. https://doi.org/10.1016/j.ecohyd.2018.07.004

Wang, X., Dong, X., Liu, H., Wei, H., Fan, W., Lu, N., ... \& Xing, K. (2017). Linking land use change, ecosystem services and human well-being: A case study of the Manas River Basin of Xinjiang, China. Ecosystem services, 27, 113-123. https://doi.org/10.1016/j.ecoser.2017.08.013

Zurbrügg, C., Gfrerer, M., Ashadi, H., Brenner, W., \& Küper, D. (2012). Determinants of sustainability in solid waste management-The Gianyar Waste Recovery Project in Indonesia. Waste management, 32(11), 2126-2133. https://doi.org/10.1016/j.wasman.2012.01.011

Received on 14-03-2021

Accepted on 06-05-2021

Published on 26-05-2021

https://doi.org/10.6000/1929-4409.2021.10.123

(C) 2021 Sidik and Lisdiyono; Licensee Lifescience Global.

This is an open access article licensed under the terms of the Creative Commons Attribution Non-Commercial License (http://creativecommons.org/licenses/by-nc/3.0/) which permits unrestricted, non-commercial use, distribution and reproduction in any medium, provided the work is properly cited. 